\title{
Jaloittelu- ja ulkotarhoista aiheutuvan vesistökuormituksen vähentäminen vaikeaa
}

Jaana Uusi-Kämppä ${ }^{1)}$, Helvi Heinonen-Tanski ${ }^{2)}$, Arto Huuskonen ${ }^{3)}$, Helena Jansson ${ }^{4)}$, Håkan Jansson ${ }^{1)}$, Miia Kuisma ${ }^{5)}$, Arja Nykänen ${ }^{5}$, Aaro Närvänen ${ }^{1)}$ ja Maarit Puumala ${ }^{6)}$

${ }^{1)}$ MTT, Kasvintuotannon tutkimus, E-talo, 31600 Jokioinen, etunimi.sukunimi@mtt.fi

${ }^{2)}$ Kuopion yliopisto, Ympäristötieteen laitos, PL 1627, 70211 Kuopio, heinonentanski@uku.fi

${ }^{3)}$ MTT, Kotieläintuotannon tutkimus, Halolantie 31 A, 71750 Maaninka, etunimi.sukunimi@mtt.fi

${ }^{4)}$ MTT, Kotieläintuotannon tutkimus, Varsanojantie 63, 32100 Ypäjä, etunimi.sukunimi@mtt.fi

${ }^{5)}$ MTT, Kasvintuotannon tutkimus, Lönnrotinkatu 3, 50100 Mikkeli, etunimi.sukunimi@mtt.fi

${ }^{6)}$ MTT, Kotieläintuotannon tutkimus, Vakolantie 55, 03400 Vihti, etunimi.sukunimi@mtt.fi

\section{Tiivistelmä}

Nautojen jaloittelu- ja ulkotarhat sekä hevostarhat ovat yleistyneet viime vuosina. Syynä on mm. parsinavetoissa olevien lehmien ja hiehojen laidunnussäännös, joka voidaan korvata jaloittelulla tarhassa. Myös suurten pihattonavettojen yhteyteen usein rakennetaan tarha, vaikka varsinaista ulkoilupakkoa pihatossa pidettävillä eläimillä ei ole. Ulkotarhoissa kasvatetaan osan vuotta tai ympäri vuoden emolehmiä ja lihanautoja. Viime vuosina hevosten määrän lisääntyessä on rakennettu uusia talleja ja tarhoja.

Varsinaisissa jaloittelutarhoissa eläimet jaloittelevat muutaman tunnin kerrallaan, mutta ulkotarhoissa ne ovat ympäri vuoden. Tarhat ovat maapohjaisia, vaihtopohjaisia tai tiivispohjaisia (asfaltista tai betonista valettuja tai sementillä stabiloituja). Osa tarhoista on perustettu metsään. Tarhoista aiheutuvaan ravinnekuormitukseen vaikuttavat monet asiat. Eläintiheys on niistä tärkein - mitä enemmän eläimiä on tarha-alaa kohti, sitä suurempi on kuormitus. Kun eläimet ovat koko vuorokauden tarhassa, kuormitus on suurempi, kuin jos ne jaloittelisivat tarhassa vain muutaman tunnin päivässä. Ruokinta-, juotto- ja makuualueiden lähiympäristössä ravinnekuormitus on suuri, olipa tarha-alaa kuinka paljon tahansa.

Peltoviljelyn aiheuttamaa vesistökuormitusta on pyritty vähentämään monilla eri toimenpiteillä. Erityisesti on kiinnitetty huomiota lannan levitysmääriin, -ajankohtaan ja -tapaan. Kasvipeitteettömässä tarhassa eläinpaine saattaa olla suuri (yli 80 nautayksikkövuorokautta hehtaarilla vuodessa; ny vrk/ha v), kun suositusten mukaan karjatilalla saa olla 1,5 lypsylehmää peltohehtaaria kohden. Sonnan ja virtsan käsittely tarhassa saattaa olla puutteellista, jolloin ravinteita voi kulkeutua sade- tai valumaveden mukana ympäristöön. Tarhavesissä ravinteiden ja ulostemikrobien pitoisuudet saattavat olla moninkertaiset pellon valumavesiin verrattuna. Tarhavedet voivat pilata lähikaivoja ja heikentää rantavesien hygieniaa sekä osaltaan lisätä vesien rehevöitymistä aina leväkukinnoiksi asti. Nautojen tarhoista aiheutuvaa ravinne- ja mikrobikuormitusta vesiin ja kuormituksen vähentämistä on tutkittu MTT:ssä kymmenisen vuotta.

Sonnan säännöllinen poisto tarhasta vähentää ravinteiden joutumista vesiin. Tiivispohjaisesta tarhasta on helpompi poistaa sonta ja kerätä valumavedet kuin maa- tai vaihtopohjaisesta tarhasta. Jos maa- tai vaihtopohjainen tarha on salaojitettu, osa vesistä saadaan kerättyä. Maa- ja vaihtopohjaisista tarhoista valumavesiä muodostuu vähemmän ja niissä on yleensä myös vähemmän fosforia, typpeä ja mikrobeja kuin tiivispohjaisen tarhan vesissä, sillä maapohja suodattaa osan epäpuhtauksista. Tiivispohjaisten tarhojen vedet suositellaankin kerättäväksi ja levitettäväksi pellolle. Maa- ja vaihtopohjaisten tarhojen vesiä ei myöskään tulisi laskea suoraan ympäristöön. Niitä voidaan puhdistaa esim. erilaisilla pienpuhdistamoilla, suodattimilla, kosteikossa tai niiden yhdistelmillä.

Asiasanat: Jaloittelutarhat, ulkotarhat, vesistönkuormitus, hevonen, nauta, fosfori, typpi, fekaaliset bakteerit 


\section{Johdanto Nautatarhat}

Jaloittelutarhassa eläimet jaloittelevat säännöllisesti joitakin tunteja päivässä tai viikossa. Toisinaan eläimet houkutellaan jaloittelutarhaan tarjoamalla niille tarhassa rehua, mutta erotuksena ulkotarhoista, varsinaiset ruokinta- ja makuupaikat ovat karjasuojassa. Ulkotarhoissa eläimet ovat yleensä vuorokauden ympäri osan vuotta tai koko vuoden.

Jaloittelutarhat voidaan jakaa vaihtopohjaisiin ja tiivispohjaisiin tarhoihin (MTT 2006). Laajat tarhat voivat olla myös vain osittain maapohjaisia. Tarhan tyyppi valitaan suunnitellun käytön perusteella. Tiiviin jaloittelutarhan pohjan tulee olla helposti puhdistettava. Se ei saa olla liukas ja sen tulee kestää hyvin talviolosuhteita. Tiivispohjaisen jaloittelutarhan päällysteeksi on tarjolla useita materiaaleja. Maabetoni on niistä halvin, mikäli pohjamaa sopii lujittamiseen. Silti betoni ja asfaltti ovat yleisimmin käytettyjä pienten jaloittelutarhojen päällysteitä. Vaihtopohjaista tarhaa perustettaessa pohjamaa muotoillaan siten, että valumavedet ohjautuvat salaojiin. Salaojitus tehdään tiuhana, noin $5 \mathrm{~m}: n$ välein, ja salaojien ympärille laitetaan salaojitushiekkaa. Vaihdettavana pintana voidaan käyttää esim. kuoriketta, haketta tai hienoa hiekkaa, jossa saa olla humustakin mukana.

Lannan kerääminen tarhasta on helpointa, jos jaloittelualue on sijoitettu siten, että lanta voidaan puskea esim. traktorin etukauhalla suoraan lantalaan. Mikäli tämä ei ole mahdollista, tarhaan on hyvä rakentaa seinämä, jota vasten lanta saadaan kerättyä etukauhaan ja siirrettyä lantalaan. Myös talvella lanta tulisi kerätä mahdollisuuksien mukaan pois, jolloin voidaan vähentää sulamisvesien mukana huuhtoutuvien ravinteiden määrää.

Valumavesien asianmukainen keräily ja käsittely ovat jaloittelutarhojen toteutuksen suuria haasteita. Karjakokoon kasvaessa tarhat laajenevat ja siten myös valumavedelle vaadittavan varastointitilan tarve kasvaa, mikä aiheuttaa huomattavia lisäinvestointi- ja työkustannuksia tiloille. Tiivispohjaisissa tarhoissa valumavesien keräilyn ongelmana on keräilykaivojen jäätyminen aikaisin keväällä ja myöhään syksyllä. Sähkövastuksen avulla kaivot saadaan pysymään sulina, mutta se kuluttaa energiaa ja menetelmän kannattavuutta on arvioitava tapauskohtaisesti. Kaivojen jäätymisen vuoksi sulamisvedet saattavat tulvia, jolloin tarvitaan "reunat" tarhan ympärille estämään hallitsematonta valumaa. Reunat tarhan ympärillä voivat olla tarpeen myös ulkopuolisten valumavesien pitämiseksi pois tarhasta, mikäli tarhan ympärillä ei ole ojaa. Myös vaihtopohjaisesta tarhasta kertyy valumavesiä, tosin huomattavasti vähemmän kuin tiiviiltä pohjalta.

Tarhan kattaminen poistaa valumavesiongelmat, mutta osa ulkoiluttamisen perimmäisestä ajatuksesta katoaa, jos tarha katetaan kokonaan ja lehmät eivät saa auringonvaloa ulkoillessaan. Runsaimmalle kuormitukselle joutuvat alueet kannattanee kattaa etenkin, jos tarha on käytössä ympäri vuoden.

\section{Hevostarhat}

Viimeisten viiden vuoden aikana on hevosten määrä Suomessa lisääntynyt keskimäärin noin 1500 hevosella vuodessa (Suomen Hippos 2007). Hevostarhojen kuten nautatarhojenkin tulee olla turvallisia ja riittävän tilavia eläimille, mutta niistä ei myöskään saa olla haittaa naapurustolle tai ympäristölle. Hevonen viettää tarhassa vähintään kuudenneksen - usein jopa yli puolet vuorokaudesta, joten tarha vaikuttaa olennaisesti hevosten hyvinvointiin (Jansson ym. 2005, Pikkarainen 2005). Hevoset ovat tarhoissa joko yksin tai laumassa. Hevostarhat ovat yleensä maa- tai vaihtopohjaisia, joiden pintakerros on hiekkaa. Tarhan pintaan kertyy sonnasta fosforia ja typpeä, jotka huuhtoutuvat helposti sade- ja sulamisvesien mukana lähistön pintavesiin (Airaksinen ym. 2007). Isoilla talleilla samaa tarhaa käyttää usea eri hevonen, jolloin myös riski tarttuvien tautien ja loisten leviämiseen hevosten kesken on suuri.

\section{Aineisto ja menetelmät}

Erilaisia nautatarhoja on tutkittu vuodesta 1997 lähtien eri puolilla Suomea. Tutkimuskohteina on ollut sekä jaloittelu- että ulkotarhoja (taulukko1). Tarhojen valumavedet on yleensä kerätty pintavalumakaivoista, tarhan kuivatukseen käytetyistä salaojista tai tarhaa ympäröivästä avo-ojasta. Tohmajärven metsätarhoissa kerättiin vajovettä, joka suotautui 30-40 cm paksun maakerroksen läpi lysimetrihin (Uusi-Kämppä 2002). Taivalkosken metsälaitumilta, joista vettä ei voitu kerätä, otettiin maanäytteitä. Maanäytteistä analysoitiin helppoliukoisen fosforin sekä liukoisen typen pitoisuudet maan pintaker- 
roksesta ja useista maakerroksista $60 \mathrm{~cm}: n$ syvyyteen asti. Tulosten avulla voitiin arvioida ravinteiden huuhtoutumisriskiä pinta- tai pohjavesiin. Ravinnekuormitukseen vaikuttavat myös tarhan koko, tarhattavien eläinten määrä ja niiden tarhassa viettämä aika. Sen vuoksi arvioitiin eläinpaine (ny vrk/ha v) jokaisessa tarhassa ja lopuksi laskettiin täysikasvuisten nautojen määrä tarhahehtaaria kohti, jos eläimet olisivat tarhassa ympäri vuoden 24 t/vrk.

Taulukko 1. Tutkimustarhojen ja -laitumien pohjamateriaalit, pinta-alat, eläimet, nautatiheydet, päivittäinen tarhassa vietetty aika, tarhapäivien määrä vuodessa ja eläinpaine.

\begin{tabular}{|c|c|c|c|c|c|c|c|}
\hline $\begin{array}{l}\text { Jaloittelu- } \\
\text { tarha } \\
\text { /Ulkotarha }\end{array}$ & $\begin{array}{l}\text { Tarha- } \\
\text { pohja }\end{array}$ & $\begin{array}{c}\text { Pinta-ala } \\
\left(\mathrm{m}^{2}\right)\end{array}$ & $\begin{array}{c}\text { Eläin- } \\
\text { määrä/tarha }\end{array}$ & $\begin{array}{l}\text { Nauta- } \\
\text { tiheys } \\
\text { (ny/ha) }\end{array}$ & $\begin{array}{l}\text { Päivit- } \\
\text { täinen } \\
\text { tarha- } \\
\text { aika } \\
\text { (t/vrk) }\end{array}$ & $\begin{array}{c}\text { Tarha- } \\
\text { päivien } \\
\text { määrä } \\
\text { vuodessa } \\
\text { (vrk/v) }\end{array}$ & $\begin{array}{c}\text { Eläin- } \\
\text { paine } \\
\text { (ny } \\
\text { vrk/ha v) }\end{array}$ \\
\hline $\begin{array}{l}\text { Juvan jaloit- } \\
\text { telutarha }^{\text {(a) }}\end{array}$ & Asfaltti & 500 & $\begin{array}{l}\text { 56-100 leh- } \\
\text { mää }\end{array}$ & $370-670$ & 3 & 330 & $42-77$ \\
\hline $\begin{array}{l}\text { Juvan jaloit- } \\
\text { telutarha }^{(b)}\end{array}$ & Kuorike & 600 & $\begin{array}{l}\text { 56-100 leh- } \\
\text { mää }\end{array}$ & $620-1100$ & 3 & 330 & $71-126$ \\
\hline $\begin{array}{l}\text { Juvan jaloit- } \\
\text { telutarha }\end{array}$ & Hiekka & 625 & 20 lehmää & 330 & 24 & 135 & 124 \\
\hline $\begin{array}{l}\text { Minkiön } \\
\text { jalottelu- } \\
\text { tarha }^{(d)}\end{array}$ & Asfaltti & 900 & $\begin{array}{l}45 \text { lehmää, } 40 \\
\text { vasikkaa }\end{array}$ & 770 & 4 & 240 & 85 \\
\hline $\begin{array}{l}\text { Tohmajärven } \\
\text { ulkotarha }^{(e)}\end{array}$ & $\begin{array}{l}\text { Asfaltti, } \\
\text { päällä kuo- } \\
\text { riketta ja } \\
\text { olkea }\end{array}$ & 570 & 8 emolehmää & 140 & 24 & 225 & 88 \\
\hline $\begin{array}{l}\text { Tohmajärven } \\
\text { metsätarha }^{(f)}\end{array}$ & $\begin{array}{l}\text { Maa (tur- } \\
\text { vetta ja } \\
\text { hiekkaa) }\end{array}$ & 4400 & 32 emolehmää & 72 & 24 & 225 & 45 \\
\hline $\begin{array}{l}\text { Ruukin } \\
\text { metsätarha }\end{array}$ & $\begin{array}{l}\text { Maa } \\
\text { (moreenia) }\end{array}$ & 10000 & 10 sonnia & 6 & 24 & 360 & 6 \\
\hline $\begin{array}{l}\text { Taivalkosken } \\
\text { metsälaitu- } \\
\text { met }^{(h)}\end{array}$ & Maa & $\begin{array}{l}130000- \\
670000\end{array}$ & $\begin{array}{l}\text { 9-16 son- } \\
\text { nia/hiehoa }\end{array}$ & $0,2-0,7$ & 24 & 360 & $0,2-0,7$ \\
\hline $\begin{array}{l}\text { Tohmajärven } \\
\text { metsälaitu- } \\
\text { met }^{(\mathrm{i})}\end{array}$ & Maa & 33000 & 6-11 nautaa & $1,8-3,3$ & 24 & $5-10$ & $0,03-0,09$ \\
\hline \multicolumn{8}{|c|}{$\begin{array}{l}\text { (a), (b) Perustettu 2000, tutkimus 2001-2007 (Uusi-Kämppä ym. 2003). } \\
\text { (c) Perustettu 2004, näytteet 2005-2007. } \\
\text { (d) Näytteet v. 1999-2000 (Uusi-Kämppä \& Heinonen-Tanski 2000, Uusi-Kämppä ym. 2001). } \\
\text { (e) Näytteet v. 1997-1999 (Uusi-Kämppä \& Heinonen-Tanski 2000, Uusi-Kämppä ym. 2001). } \\
\text { (f) Perustettu 1995, vajovesinäytteitä } 0.3 \text { m:n syvyydestä ruokintapaikan ympäristössä v. 1998-2000 (Uusi- } \\
\text { Kämppä 2002). } \\
\text { (g) Näytteet ojavedestä v. 2000-2002 (Uusi-Kämppä ym. 2003, Uusi-Kämppä ym. 2007b). } \\
\text { (h) (Uusi-Kämppä ym. 2006b). } \\
\text { (i) (Uusi-Kämppä ym. 2006a). }\end{array}$} \\
\hline
\end{tabular}

Hevostarhojen valumavesiä on tutkittu Ypäjän hevosopiston alueella, jossa on selvitetty ferrisulfaattilisäyksen vaikutusta tarhaveden fosforipitoisuuksiin ja mikrobitiheyksiin (Närvänen ym. 2008). Kuuman tallilla Jokioisissa on kokeiltu haketta tarhan pohjamateriaalina. Hakkeen läpi suotautuneet vedet on kerätty salaojista ravinnemäärityksiin. Tarhoista otettiin myös pintamaata, jota sadetettiin laboratoriossa (Uusi-Kämppä ym. 2007c). Sadetuksen aikana maan pinnalle kertynyt vesi kerättiin ravinne- ja mikrobianalyyseihin. 


\section{Tulokset}

\section{Ravinnekuormituksen suuruus}

Tarhoista aiheutuvaan ravinnekuormitukseen vaikuttavat monet asiat. Eläintiheys on niistä tärkein mitä enemmän eläimiä on tarha-alaa kohti, sitä suurempi on kuormitus (Uusi-Kämppä ym. 2006b). Jos eläimet ovat koko vuorokauden tarhassa, kuormitus on suurempi kuin, jos ne jaloittelisivat tarhassa vain muutaman tunnin päivässä. Ulkotarhoissa, joissa eläimet ovat jatkuvasti, kuormitus voi olla hyvin suurta. Ruokinta-, juotto- ja makuualueiden ympäristössä kuormitus on suuri, olipa tarha-alaa kuinka paljon tahansa (Uusi-Kämppä ym. 2006b). Taivalkosken metsälaitumilla, joissa eläintiheys oli pieni (< 1 ey/ha), maan fosfori- ja typpipitoisuudet olivat yleensä samaa tasoa kuin laiduntamattomassa metsämaassa. Poikkeuksena olivat ruokinta- ja makuupaikat, joissa karja vietti runsaasti aikaa. Kuormittuneimmilla alueilla $60 \mathrm{~cm}: n$ maakerroksessa oli ammoniumtyppeä 100-1000 kg ha ${ }^{-1}$. Vastaavasti maan pintakerroksessa oli helppoliukoista fosforia 20-140 $\mathrm{mg} \mathrm{l}^{-1}$, mikä peltoviljelyssä vastaa viljavuusluokkia hyvä, korkea tai arveluttavan korkea (Uusi-Kämppä ym. 2006b). Tohmajärvellä tarhattaessa emolehmiä talvikauden ajan metsätarhoissa, sekä pintamaan että 30-40 cm:n syvyydestä kerätyn vajoveden fosfori- ja typpipitoisuudet olivat suuria (Uusi-Kämppä 2002). Sielläkin suurin ravinnekuormitus mitattiin ruokintapaikkojen ympäristöstä. Ruotsissa sikojen ulkokasvatusalueella havaittiin eläinten ulostavan pääasiassa lepo-, ruokinta- ja juottopaikkojen läheisyyteen (Salomon ym. 2007). Näissä paikoissa myös maan ravinnepitoisuudet olivat suuremmat kuin muualla tarhassa.

Taulukko 2. Mediaanit nautatarhojen valumavesien fosfori- ja typpipitoisuuksista.

\begin{tabular}{llccccc}
\hline $\begin{array}{l}\text { Jaloittelutarha } \\
\text { /Ulkotarha }\end{array}$ & $\begin{array}{l}\text { Vesinäytteen } \\
\text { ottopaikka } \\
\text { (näytteiden lu- } \\
\text { kumäärä) }\end{array}$ & $\begin{array}{c}\text { Liukoinen } \\
\text { fosfori } \\
\text { (mg/l) }\end{array}$ & $\begin{array}{c}\text { Kokonais- } \\
\text { fosfori } \\
\text { (mg/l) }\end{array}$ & $\begin{array}{c}\text { Ammoni- } \\
\text { umtyppi } \\
\text { (mg/l) }\end{array}$ & $\begin{array}{c}\text { Nitraatti- } \\
\text { typpi } \\
\text { (mg/l) }\end{array}$ & $\begin{array}{c}\text { Koko- } \\
\text { naistyp- } \\
\text { pi (mg/l) }\end{array}$ \\
\hline $\begin{array}{l}\text { Juvan jaloittelu- } \\
\text { tarha: Asfaltti }\end{array}$ & $\begin{array}{l}\text { Pintavalunta- } \\
\text { kaivo (44) }\end{array}$ & 26,6 & 48,9 & 55,8 & 0 & 149 \\
\hline $\begin{array}{l}\text { Juvan jaloittelu- } \\
\text { tarha: Kuorike }\end{array}$ & $\begin{array}{l}\text { Salaojakaivo } \\
\text { (37) }\end{array}$ & 0,06 & 4,81 & 35,2 & 0 & 55,6 \\
\hline $\begin{array}{l}\text { Juvan jaloittelu- } \\
\text { tarha: Hiekka }\end{array}$ & Salaojakaivo (6) & 0,03 & 1,46 & 8,10 & 25,4 & 40,6 \\
\hline $\begin{array}{l}\text { Minkiön jalottelu- } \\
\text { tarha: Asfaltti }\end{array}$ & $\begin{array}{l}\text { Pintavalunta- } \\
\text { kaivo (31) }\end{array}$ & 21,6 & 39,5 & 64 & 0,07 & 173 \\
\hline $\begin{array}{l}\text { Tohmajärven ulko- } \\
\text { tarha: Asfaltti }\end{array}$ & Kaivo (35) & 53 & 73,5 & 129 & 0,2 & 253 \\
\hline $\begin{array}{l}\text { Tohmajärven } \\
\text { metsätarhan } \\
\text { ruokintapaikat }\end{array}$ & Vajovesi (25) & 0,04 & 3,6 & 440 & 0,09 & 535 \\
\hline Ruukin metsätarha & Ojavesi (324) & 0,15 & 0,35 & 0,69 & 0 & 1,7 \\
\hline $\begin{array}{l}\text { Tohmajärven } \\
\text { metsälaidun }\end{array}$ & Ojavesi (48) & 0,01 & 0,02 & 0,03 & 0,65 & 1,1 \\
\hline
\end{tabular}

Tarhavesien ravinnepitoisuudet olivat suurimmat tiivispohjaisissa tarhoissa (taulukko 2). Esimerkiksi suurimmat fosfori- ja kokonaistyppipitoisuudet mitattiin asfalttipohjaisten tarhojen pintavalumista. Tarhoissa, joissa pohjamateriaali oli läpäisevää, osa fosforista ja typestä pidättyi vaihtopohjaan ja maahan, kun vesi suotautui niiden läpi. Typpi oli pääasiassa ammoniummuodossa. Myös eläinpaineella oli merkitys tarhaveden ravinnepitoisuuksiin. Ruukin metsätarhan ojavesissä ravinnepitoisuudet vastasivat peltoveden pitoisuuksia. Syynä pieniin pitoisuuksiin oli pieni eläinpaine (6 ny vrk/ha v) ja ojaveden osittainen laimeneminen tarhaa ympäröivän metsän vesillä. Tosin tarha-alueella oli vaarana liukoisten ravinteiden osittainen suotautuminen karkean moreenimaa-aineksen läpi pohjaveteen. Tohmajärven metsätarhassa ammoniumtypen pitoisuus oli suuri 30-40 cm:n syvyydellä olevassa vajovedessä.

Sadetettujen hevostarhapohjien pintavalumissa oli suuria liukoisen ja kokonaisfosforin pitoisuuksia (Taulukko 3). Jos tarhasta ei ollut poistettu lantaa, pitoisuus oli suurempi kuin puhdistetussa tarhassa. Vastaavaan päätelmään oli aiemmin päädytty Airaksisen ym. (2007) hevostarhatutkimuksessa. Kalsiumhydroksidin lisäys tarhan pintaan pienensi sadetuskokeessa valumaveden fosforipitoisuut- 
ta. Sadetuskokeessa saadut pitoisuudet ovat suurempia kuin luonnonolosuhteissa mitatut pitoisuudet, mutta ne kertovat kuitenkin, millaisista tarhoista lähtee valumaveden mukana enemmän ja millaisista vähemmän ravinteita ja mikrobeja.

Taulukko 3. Eläinpaine hevostarhoissa sekä fosfori- ja typpipitoisuudet sadetettujen tarhapohjien pintavalumavesissä elokuussa 2006. (Suluissa tarhan koko ja tarhan käyttöönottovuosi)

\begin{tabular}{lllll}
\hline Tarha & Eläimet & $\begin{array}{l}\text { Eläinpaine, } \\
\text { ey vrk/ha v }\end{array}$ & $\begin{array}{l}\text { Liukoinen fos- } \\
\text { fori, mg/l }\end{array}$ & $\begin{array}{l}\text { Kokonais-fosfori, } \\
\mathrm{mg} / \mathrm{l}\end{array}$ \\
\hline Sepelipohjainen $\left(710 \mathrm{~m}^{2}\right)$ & $\begin{array}{l}1-2 \text { hevosta } \\
12 \mathrm{t} / \mathrm{vrk}(2005-)\end{array}$ & $7-14$ & 1,39 & 1,84 \\
\hline $\begin{array}{l}\text { Sepelipohjainen }\left(710 \mathrm{~m}^{2}\right), \\
\text { sontimispaikka }\end{array}$ & $\begin{array}{l}1-2 \text { hevosta } \\
12 \mathrm{t} / \mathrm{vrk}(2005-)\end{array}$ & $7-14$ & 36,7 & 41,5 \\
\hline Hiekkapohjainen $\left(520 \mathrm{~m}^{2}\right)$ & $\begin{array}{l}1-3 \text { hevosta } \\
12 \mathrm{t} / \mathrm{vrk}(2003-)\end{array}$ & $10-29$ & 9,72 & 11,2 \\
\hline $\begin{array}{l}\text { Hiekkapohjainen }\left(520 \mathrm{~m}^{2}\right), \\
\text { Ca(OH) })_{2} \text {-lisäys }\end{array}$ & $\begin{array}{l}1-3 \text { hevosta } \\
12 \text { t/vrk (2003-) }\end{array}$ & $10-29$ & 0 & 1,65 \\
\hline Hakepohjainen $\left(950 \mathrm{~m}^{2}\right)$ & $\begin{array}{l}3-4 \text { hevosta } \\
11 \mathrm{t} / \mathrm{vrk}(2005-)\end{array}$ & $14-19$ & 9,87 \\
\hline Savipohjainen $\left(800 \mathrm{~m}^{2}\right)$ & $\begin{array}{l}4 \text { hevosta } 11 \mathrm{t} / \mathrm{vrk} \\
(2001-)\end{array}$ & 23 & 2,00 & 4,26 \\
\hline
\end{tabular}

\section{Ulosteesta peräisin olevien mikrobien tiheydet valumavesissä}

Ulosteesta peräisin olevien mikrobien tiheydet olivat suurimmat tarhoissa, joissa oli suuri eläinpaine ja tiivis pohja. Mikrobitiheydet ja ravinnepitoisuudetkin olivat pienemmät maapohjaisissa tarhoissa. Fekaalisten koliformien pitoisuudet maapohjaisten tarhojen valumavesissä olivat vain noin $1 \%$ vastaavista pitoisuuksista asfalttipohjaisissa tarhoissa (Uusi-Kämppä ym. 2007a). Lintupajun suojakaistakoekentällä on todettu fekaalisten koliformien tiheyksien pienenevän laitumen pintavalumissa, jos laitumen ja vesistön väliin jätetään 10 m levä laiduntamaton suojakaista (Rasa ym. 2007). Kun eläinpaine tarhoissa oli yli 45 ny vrk/ha v, fekaalisten koliformien tiheydet tarhavesissä $\left(10^{4}-10^{6} \mathrm{pmy} / 100 \mathrm{ml}\right.$; pmy=pesäkkeen muodostava yksilö) ylittivät aina uimavedelle asetetut raja-arvot (500 pmy/100 ml) ja olivat samalla tasolla kuin jäteveden puhdistamoilta lähtevissä jätevesissä (Koivunen ym. 2003). Myös hevostarhoissa fekaalisten koliformien tiheydet olivat suuria: $10^{3}-10^{4} \mathrm{pmy} / 100 \mathrm{ml}$ (Uusi-Kämppä ym. 2007a).

\section{Kuormituksen vähentämiskeinoja}

Sonnan säännöllinen poisto sekä nautojen että hevosten tarhoista vähentää kuormitusta. Sonnasta peräisin olevat ravinteet ja mikrobit kulkeutuvat tarhasta pääasiassa sade- ja sulamisvesien mukana. Siten valumavesien kerääminen ja levittäminen pellolle kasvukaudella tai niiden puhdistaminen ovat suositeltavia tapoja, kun pienennetään nautaeläimien tarhoista aiheutuvaa kuormitusta vesiin. Ravinteiden lisäksi tarhavesissä on runsaasti ulostemikrobeja, joiden pääsy talous-, uima- tai vihannesten kasteluveteen on estettävä. Tarhaveden määrää kannattaa pienentää estämällä tarhan ulkopuolisten vesien pääsy tarhaan. Yhden kahden hevosen tarhoissa tulee jättää riittävä etäisyys tarhan ja ojan tai vesistön välille, jotta tarhavedet eivät likaisi niitä. Jos talilla on useampia hevosia, niin tarhavesien kerääminen ja käsittely ovat niissäkin tarpeellisia toimenpiteitä.

Minkiön jaloittelutarhavesiä puhdistettiin erilaisilla maasuodattimilla. Suodattimet poistivat aluksi hyvin fosforia ja typpeä. Noin vuoden kuluttua ne kuitenkin tukkeutuivat ja niiden puhdistusteho heikkeni (Uusi-Kämppä ym. 2001). Suodattamien tukkeutumista voidaan vähentää poistamalla vedestä kiintoaines, ennen kuin se johdetaan suodattimiin. Tarhavesiä voidaan myös käsitellä kemikaaleilla ja sakkauttaa liukoinen fosfori laskeutusaltaassa, kuten Ypäjän hevostarhoissa on tehty (Närvänen ym. 2008).

Vaihtopohjaisissa ja maapohjaisissa tarhoissa pintamateriaaliin kertyy ravinteita aikaa myöten ja säännöllisellä materiaalin vaihdolla voidaankin vähentää tarhasta ympäristöön kohdistuvaa kuormitusta. Nautojen tarhoista poistettu materiaali on esim. levitettävä peltoon, jotta ravinteet saadaan hyödyn- 
nettyä. Hevostarhojen kiviainekselle ei yhtä helposti löydy kierrätyskäyttöä kuin nautojen tarhoissa käytetyille materiaaleille.

\section{Johtopäätökset}

Nautojen ja hevosten tarhavesistä aiheutuva ravinnekuormitus ja hygieniahaitat on otettava huomioon, kun tarhoja suunnitellaan, rakennetaan ja hoidetaan. Tarhat on rakennettava niin, että niistä saadaan pinta- ja salaojavedet kerättyä ja käsiteltyä. Toistaiseksi ympäristön kannalta paras tapa lienee tarhaveden levittäminen pellolle kasvukaudella. Myös vesien puhdistamissysteemejä tulee parantaa ja kehittää. Tarhavesien mukana kulkeutuvat ulostemikrobit saattavat aiheuttaa pahimmassa tapauksessa epidemioita, jos tarhavedet pääsevät esimerkiksi talous- tai uimaveden joukkoon. Laidun, jota käytetään intensiivisesti nautojen ulkoiluun, muistuttaa pian enemmän jaloittelutarhaa kuin varsinaista laidunta. Tällainen laidun kuormittaa ympäristöä samalla lailla kuin jaloittelutarha. Tällaisissa tapauksissa laitumen ja ojan tai vesistön välissä tulisikin olla riittävä suojaetäisyys. Laidunalueen tulee myös olla muussa viljelykäytössä välillä. Tarhavesienkäsittelyä mietittäessä tulee ottaa huomioon kuormituksen suuruus. Kuormitus on pientä yhden kahden hevosen tarhassa ( $<2$ ey vrk/ha v) verrattuna isoon lihanautatarhaan, jossa eläinpaine on suuri ( $>40$ ny vrk/ha v). Nautojen ja hevosten lisäksi tarhataan poroja ja jonkin verran myös sikoja, strutseja muita eläimiä (Kuisma 2006, Nieminen 2006). Myös näiden eläinryhmien käytössä olevien tarhojen ravinnekuormitus ja hygieniahaitat on minimoitava.

\section{Kirjallisuus}

Airaksinen, S., Heiskanen, M-L. \& Heinonen-Tanski, H. 2007. Contamination of surface run-off water and soil in two horse paddocks. Bioresource Technology 98: 1762-1766.

Jansson. H., Närvänen, A., Perälä, P. \& Jansson, H. 2005. Report on the results of the survey of nutrient load from different equine areas. Saatavissa internetistä:

http://www.equinelife.fi/files/nutrient_load_from_equine_areas.pdf

Koivunen, J., Siitonen, A. \& Heinonen-Tanski, H. 2003. Elimination of enteric bacteria in biological-chemical wastewater treatmetn and tertiary filtration units. Water Research 37: 690-698.

Kuisma, M. 2006. Jaloittelutarhoista on avattu nettisivusto. Koetoiminta ja käytäntö 63, 2 12.6.2006): 16. Saatavissa internetistä: http://www.mtt.fi/koetoiminta/pdf/mtt-kjak-v63n02s16b.pdf

MTT 2006. Jaloittelutarhat. Saatavissa interbnetistä: http://www.mtt.fi/tutkimus/kasvit/tarhat/

Nieminen, M. 2006. Porojen ruokinta. Poromies-lehti 4/2006. Julkaisupäivä 15.9.2006. Saatavissa internetistä: http://www.paliskunnat.fi/default.aspx?kieli=fi-FI

Närvänen, A., Jansson, H., Uusi-Kämppä, J., Jansson, H., \& Perälä, P. 2008. Phosphorus load from equine critical source areas and its reduction using ferric sulphate. Boreal Environment Research 13: xxx-xxx. In press. Pikkarainen, M. 2005. Hevosten hyvinvointi ja lajinmukainen käyttäytyminen sekä niiden toteutuminen suomalaisilla talleilla. Opinnäytetyö. HAMK, Mustiala. 51 s. Saatavissa internetistä:

www.equinelife.fi/files/opinnayte hevostenhyvinvointi.pdf

Rasa, K., Räty, M. \& Uusi-Kämppä, J. 2007. Suojavyöhykkeen iän ja hoidon vaikutus suojavyöhykkeen toimintaan (lyhenne SUOTO). Pro Terra 34/2007. Helsingin yliopisto, Soveltavan kemian ja mikrobiologian laitos. $64 \mathrm{~s}$.

Salomon, E., Åkerhielm, H., Lindahl, C. \& Lindgren, K. 2007. Outdoor pig fattening at two Swedish organic farms-Spatial and temporal load of nutrients and potential environmental impact. Agriculture, Ecosystems and Environment 121: 407-418.

Suomen Hippos 2007. Hevoskannan kehitys maassamme 1910-2005. Saatavissa internetistä: http://www.hippos.fi/hippos/tilastot/jalostus_ja_kasvatus/hevoskannan_kehitys.php

Uusi-Kämppä, J. 2002. Nitrogen and phosphorus losses from a forested feedlot for suckler cows. Agricultural and Food Science in Finland 11: 355-369.

Uusi-Kämppä, J., Grék, K., Jansson, H. 2001. Ulkotarhojen vesistökuormitus. Teoksessa: Manninen, Merja (toim.) Hyvinvoivat naudat puhtaassa ympäristössä -loppuraportti. Jokioinen: Maa- ja elintarviketalouden tutkimuskeskus. p. 67-79.

Uusi-Kämppä, J., Grék, K., Laasonen, M., Seppänen, A. \& Virkajärvi, P. 2006a. Lyhytkestoisen metsälaidunnuksen aiheuttama vesistökuormitus . Teoksessa: Huuskonen, A. (toim.). LUMOLAIDUN: Maisemalaiduntaminen luonnon monimuotoisuuden lisääjänä - tasapaino monimuotoisuuden ja tuottavuuden välillä. Maaja elintarviketalous 79: s. 261-274. Saatavissa internetistä: http://www.mtt.fi/met/pdf/met79.pdf Verkkojulkaisu päivitetty 22.8.2006.

Uusi-Kämppä, J. \& Heinonen-Tanski, H. 2000. Ulostemikrobit jaloittelualueen ja ulkotarhan valumavesissä. Pro Terra 4/2000. Maaperätieteiden päivien laajennetut abstraktit. 123-125. 
Uusi-Kämppä, J., Huttu, S. \& Huuskonen, A. 2006b. Ympärivuotisen metsälaidunnuksen aiheuttama typpi- ja fosforikuormitus Taivalkoskella. Teoksessa: Huuskonen, A. (toim.) LUMOLAIDUN: Maisemalaiduntaminen luonnon monimuotoisuuden lisääjänä tasapaino monimuotoisuuden ja tuottavuuden välillä. Maa- ja elintarviketalous 79: 387-395. Saatavissa internetistä: http://www.mtt.fi/met/pdf/met79.pdf Verkkojulkaisu päivitetty 22.8.2006.

Uusi-Kämppä, J., Hyvärinen, M., Kuisma, M., Nykänen, A., Jansson, H., Jansson, H. \& Närvänen, A. 2007a. Faecal microorganisms in runoff from cattle and horse farms; quantification and mitigation. Teoksessa: Aland, A. (toim.). XIII International Congress in Animal Hygiene ISAH-2007, June 17-21, 2007, Tartu, Estonia. Animal Health, Animal Welfare and Biosecurity. Proceedings volume 2. p. 909-914.

Uusi-Kämppä, J., Jauhiainen, L. \& Huuskonen, A. 2007b. Phosphorus and nitrogen losses to surface waters from a forested feedlot for bulls in Finland. Soil Use and Management 23, Supp. 1: 82-91.

Uusi-Kämppä, Närvänen, A., Jansson, H. \& Jansson, H. 2007c. Hevostarhojen fosforit ja mikrobit kuriin. Maaseudun tiede 64, 2 (22.10.2007):10. Saatavissa internetistä: http://www.mtt.fi/maaseuduntiede/pdf/mtt-mtv64n02s10b.pdf

Uusi-Kämppä, J., Puumala, M., Nykänen, A., Huuskonen, A., Heinonen-Tanski, H. \& Yli-Halla, M. 2003. Ulko- ja jaloittelutarhojen rakentaminen ja tarhoista aiheutuva ympäristökuormitus. Teoksessa: Jaana UusiKämppä, Markku Yli-Halla ja Kaarina Grék (toim.). Lypsykarjataloudesta tulevan ympäristökuormituksen vähentäminen. Maa- ja elintarviketalous 25: 48-93. Saatavissa internetistä: http://www.mtt.fi/met/pdf/met25.pdf Verkkojulkaisu päivitetty 23.05.2003 